\title{
Pesticide impact study in the peri-urban horticultural area of Gran La Plata, Argentina
}

\author{
Tomás M. Mac Loughlin, Leticia Peluso, Damián J.G. Marino* \\ Centro de Investigaciones del Medio Ambiente (CIMA), Facultad de Ciencias Exactas, Universidad Nacional de La Plata, La Plata, Buenos Aires, Argentina \\ Consejo Nacional de Investigaciones Científicas y Técnicas (CONICET), Buenos Aires, Argentina
}

\section{H I G H L I G H T S}

- Herbicides and insecticides were detected in all the bottom-sediment samples analyzed.

- Glyphosate was detected in a watercourse near a horticultural production area.

- Lethal and sublethal effects were observed in bioassays using Hyalella curvispina.

- The observed toxicity was associated mainly with insecticides.

- Pesticides from horticultural production impact aquatic environments.

\section{A R T I C L E I N F O}

\section{Article history:}

Received 30 January 2017

Received in revised form 13 April 2017

Accepted 15 April 2017

Available online $\mathrm{xxxx}$

Editor: D. Barcelo

\section{Keywords:}

Horticulture

Pesticide pollution

Sediment toxicity testing

Hyallela curvispina

\section{G R A P H I C A L A B S T R A C T}

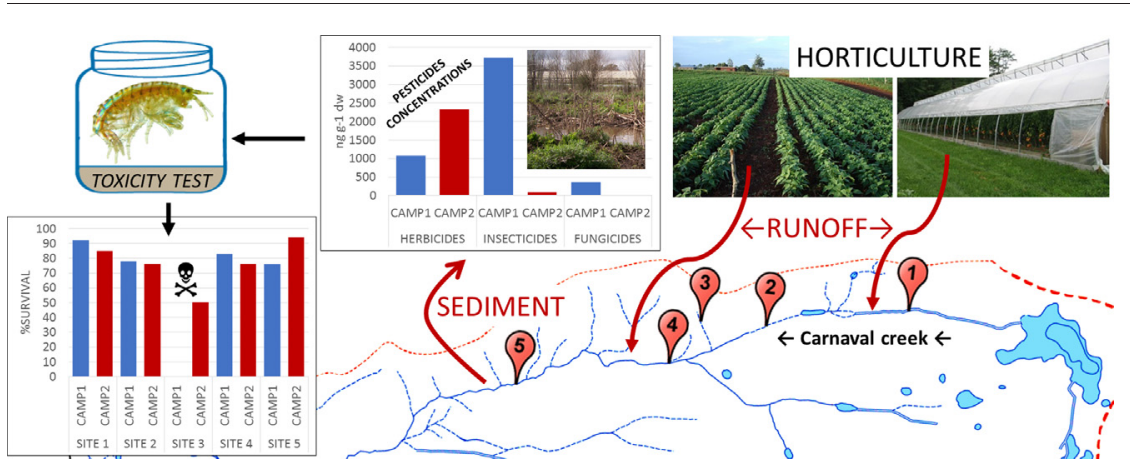

\section{A B S T R A C T}

Vegetable production systems are characterized by intense pesticide use, yet the effects on the surrounding environment are largely unknown and need to be studied. Given this knowledge gap, the objective of this work is to determine the impact of horticulture on a representative watercourse by conducting an integrated study of the occurrence and concentration of pesticides in bottom sediments and their relation to lethal and sublethal effects on benthic fauna. Two sampling campaigns were conducted during seasons of low and high pesticide application in five sites along the Carnaval creek, located in the peri-urban area of La Plata City (Buenos Aires, Argentina). The samples were tested for 36 pesticide compounds by GC-MS and LC-MS, and whole-sediment laboratory toxicity tests were performed using the native amphipod Hyalella curvispina. The results showed a general but variable distribution in the concentrations detected along the stream. For each sampling campaign (first/second), the total pesticide loads, measured as the sum of herbicides, insecticides and fungicides, were 1080/2329, 3715/88, and $367 / 5 \mathrm{ng} \mathrm{g}^{-1} \mathrm{dw}$, respectively. Lethal and sublethal effects were observed in both sampling campaigns. In order to correlate both sets of results, data were assessed by multivariate analysis, including principal component analysis. The observed toxicity was considered to be mainly due to insecticides; thus, horticultural practices have an impact on nearby watercourses and can potentially endanger the benthic fauna. This is the first study in $\mathrm{Ar}$ gentina to assess the impact of pesticides on aquatic environments close to horticultural production areas.

(c) 2017 Elsevier B.V. All rights reserved.

\footnotetext{
* Corresponding author.

E-mail address: damianm@quimica.unlp.edu.ar (D.J.G. Marino).
}

\section{Introduction}

The extensive monoculture of grains and oilseeds (maize, wheat, and soybeans) is the main agricultural activity in Argentina 
(Leguizamón, 2013). As a consequence, the number of pests attacking those crops is limited and the compounds used to control them are few (mainly glyphosate, chlorpyriphos, and cypermethrin). In contrast, horticultural production is significantly more diverse in terms of both plant species and associated pests. Production units are often small and heavily cultivated, requiring a wider range of pesticides (DP, 2015). In the Argentine pesticide market, herbicides (glyphosate, 2,4D, atrazine) account for $86.8 \%$ of total sales, while insecticides (cypermethrin, chlorpyriphos, lambda-cyhalothrin) account for $6.2 \%$, and fungicides (epoxiconazole, tebuconazole, metconazole) account for only 2.7\% (PwC, 2014). Although this represents the sum of pesticides in extensive agriculture and horticulture, the most used insecticides and fungicides are the same for both agricultural activities, and they are being more heavily used in horticulture than herbicides (DP, 2015).

In the last 20 years, the horticultural belt in the outskirts of La Plata, Buenos Aires, Argentina (Cinturón Hortícola Platense, CHP), has grown in terms of size and productivity as well as in importance in the country. The last official census shows the CHP comprises 2880 ha of vegetable production, out of which $65.6 \%$ are open fields and $34.4 \%$ are under cover (CHBA, 2006). One of the factors that has facilitated and even boosted this expansion has been the early, committed and ongoing adoption of pesticide-intensive greenhouse technology. According to a recent government report (DP, 2015), up to 168 pesticide active ingredients are applied in the CHP.

As a consequence of this kind of pesticide-intensive horticultural activity, in several regions of the world, pesticide residues can be found both in food produce (Donkor et al., 2015) and in the environment surrounding horticultural production areas (Thoma and Nicholson, 1989; Rosendahl et al., 2009; Kreuger et al., 2010; Roseth and Haarstad, 2010).

Runoff is one of the main sources of diffuse pesticide pollution in surface water bodies (Jergentz et al., 2005). This process can mobilize pesticides in the soluble phase as well as pesticides sorbed onto suspended particulate matter from soil dragged by storm water erosion (Kronvang et al., 2004). Over time, those suspended particles settle down in the bottom of water bodies. Consequently, bottom sediments constitute an important sink for these compounds (Burton and Landrum, 2003) and can thus be used as an integrated measure of pesticide input on the hydrological system (Friberg et al., 2003).

Since bottom sediments provide nutrients and habitat for a wide variety of benthic organisms, sediment quality evaluation becomes relevant for the protection of aquatic life (Paixão et al., 2011). Wholesediment toxicity tests provide a good methodology to assess the bioavailability of pollutants to these organisms (Hintzen et al., 2009) and allow for the evaluation of interaction effects resulting from the complex mixture of components in sediments (Peluso et al., 2013a, 2013b). In this sense, amphipods are model species for this type of toxicity bioassay (USEPA, 2000). Hyalella curvispina is a native South American species found in streams in the study area (Ronco et al., 2008) but not in areas impacted by agricultural activity (Solis et al., 2016), suggesting that it is a species sensitive to the presence of pesticides in sediments (Jergentz et al., 2005; Phillips et al., 2006).

Despite the significance of agriculture in the country, published data on pesticide occurrence in aquatic environments in the most heavily cultivated area of Argentina (Buenos Aires, Córdoba and Santa Fe Provinces) remains scarce. Most studies focus on the Buenos Aires Province (Jergentz et al., 2005; Marino and Ronco, 2005; Ronco et al., 2008;De Gerónimo et al., 2014; Hunt et al., 2016), and only some take into consideration the productive area in its entirety (Ronco et al., 2016; Etchegoyen et al., 2017). Moreover, there is no information on the impact of pesticides on water bodies associated with horticulture; and very little research has been done in other countries (Thoma and Nicholson, 1989; Kreuger et al., 2010; Roseth and Haarstad, 2010).

The objective of this work is to determine the impact of pesticides on a watercourse that flows through a highly productive horticultural zone by conducting a bottom-sediment integrated study of the occurrence and concentration of pesticides and their relation to lethal and sublethal effects on benthic fauna.

\section{Materials and methods}

\subsection{Study area}

The Carnaval creek and its tributaries (Fig. 1) constitute a suburban basin located in the La Plata area in the northeast of the Buenos Aires Province, Argentina. The basin has a surface area of $105 \mathrm{~km}^{2}$. Its urbanization coefficient is estimated at $15 \%$ to $20 \%$. Its main channel originates in the García Lagoon, has a length of $14.5 \mathrm{~km}$ and an average depth of $0.8 \mathrm{~m}$, and shows high turbidity and low current velocity. In the upper and middle part of the basin, the main land-use activities are horticulture and floriculture, and to a much lesser extent, extensive crops like soybeans, maize and wheat. In the CHP, there are $>1000$ parcels that produce and condition vegetables for distribution and commercialization. The highest population density - along with some industries - is concentrated in the lower basin (Banda Noriega and Ruiz de Galarreta, 2002).

\subsection{Sampling}

Integrated sediments samples were collected during two monitoring campaigns in August 2015 (CAMP1) and January 2016 (CAMP2), following cycles of low and high pesticide use, respectively (Marino and Ronco, 2005). Sampling was performed at 5 sites along the Carnaval creek (S1-S5). At each site, sediments were collected for both chemical analysis and toxicity bioassays in $2 \mathrm{~L}$ containers. The sediment samples were obtained in shallow water, and the first $5 \mathrm{~cm}$ were taken using an Eckman grab. The samples were preserved in an ice-cold container until arrival at the laboratory (ASTM, 2002), where each sample was homogenized. A subsample of the homogenized sediment was separated in a $200 \mathrm{~mL}$ container for pesticide residue analysis and stored at $-20{ }^{\circ} \mathrm{C}$ until the analysis. The subsample for the toxicity bioassay was preserved at $4{ }^{\circ} \mathrm{C}$ in darkness until its use (Peluso et al., 2013a, 2013b). Dry weight was measured at $105^{\circ} \mathrm{C}$ until constant mass, and organic matter content was determined by calcination at $550{ }^{\circ} \mathrm{C}$ (loss on ignition) (APHA, 1998).

\subsection{Chemicals and reagents}

Pesticide-residual-grade dichloromethane, $n$-hexane, HPLC grade acetonitrile and methanol were all obtained from J. T. Baker (USA). The 9-fluorenylmethyl chloroformate (FMOC-Cl) for HPLC derivatization, primary-secondary amine (PSA), standards of glyphosate (99\%), AMPA (98.5\%), glyphosate- $2-{ }^{13} \mathrm{C},{ }^{15} \mathrm{~N}\left(99\right.$ atom $\%{ }^{13} \mathrm{C}, 98$ atom $\%{ }^{15} \mathrm{~N}$; $\left.{ }^{13} \mathrm{C},{ }^{15} \mathrm{~N}-\mathrm{GLY}\right)$, and atrazine- $\mathrm{D}_{5}\left(\right.$ ATZ- $\left.\mathrm{D}_{5}\right)$ were acquired from Sigma $\mathrm{Al}$ drich (St. Louis, MO, USA). A Sartorius Arium water purification system (Sartorius AG, Göttingen, The Netherlands) was used to obtain nanopure water in the laboratory. Sodium chloride $(\mathrm{NaCl})$, anhydrous magnesium sulfate $\left(\mathrm{MgSO}_{4}\right)$, potassium phosphate dibasic $\left(\mathrm{K}_{2} \mathrm{HPO}_{4}\right)$, and ammonium acetate $\left(\mathrm{NH}_{4} \mathrm{Ac}\right)$ (all analytical grade) were obtained from Merck (Darmstadt, F.R. Germany). Certified standards of pesticides as $1000 \mathrm{ng} \mathrm{mL}^{-1}$ standard stock solutions in $n$-hexane were obtained from AccuStandard, Inc. (USA).

\subsection{Chemical analysis}

\subsubsection{Extraction}

One portion of $7 \mathrm{~g}$ of wet sediment was weighed into a $50 \mathrm{~mL}$ polypropylene tube. In each sample, ATZ- $\mathrm{D}_{5}$ was added as an internal quality standard at nominal concentration at the instrumental detection of $100 \mathrm{ng} \mathrm{mL}^{-1}$. The multiresidue QuEChERS method was used for pesticide extraction (Anastassiades and Lehotay, 2003), using the modification proposed by Kvíčalová et al. (2012), where $2 \mathrm{~g}$ of $\mathrm{NaCl}$ and $6 \mathrm{~g}$ of anhydrous $\mathrm{MgSO}_{4}$ were used for extraction without buffer media. To the spiked 


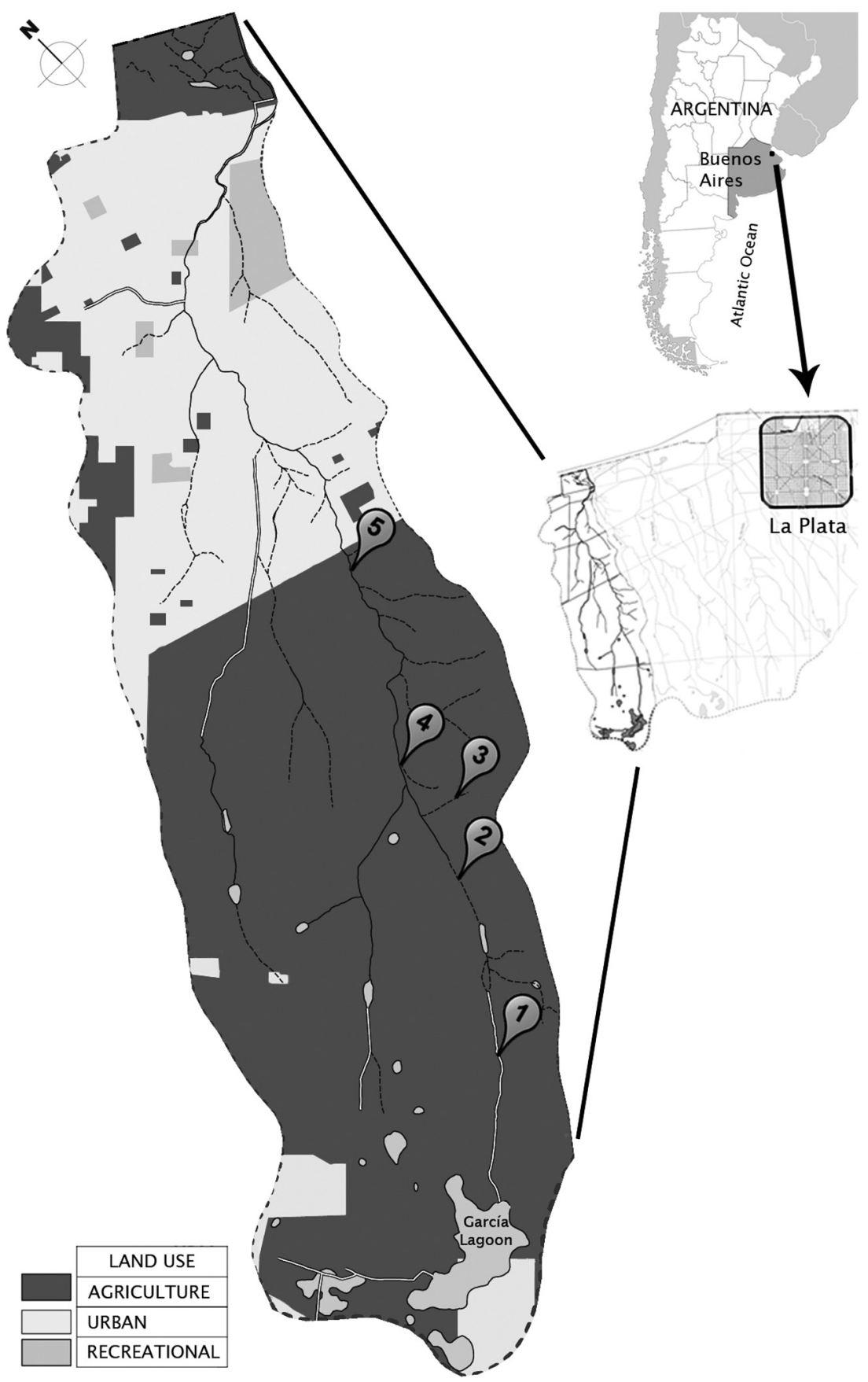

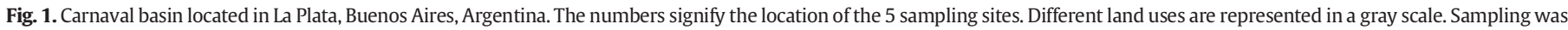
done in the lower basin, where horticulture is the main land use activity.

sediment, $15 \mathrm{~mL}$ of acetonitrile were added and sonicated for $10 \mathrm{~min}$, shaken for $1 \mathrm{~min}$ and sonicated again. The salts were poured into the mixture, which was then shaken manually for $2 \mathrm{~min}$ and centrifuged for $10 \mathrm{~min}$ at $3000 \mathrm{~g}$. Two milliliters of supernatant was cleaned with $100 \mathrm{mg}$ PSA and $300 \mathrm{mg} \mathrm{MgSO}$. The clean extract was dried under a stream of nitrogen and resuspended in $n$-hexane for instrumental analysis.

Another $7 \mathrm{~g}$ of wet sediment were weighed into a $50 \mathrm{~mL}$ polypropylene tube and used for the extraction of GLY + AMPA. As an internal quality standard, ${ }^{13} \mathrm{C},{ }^{15} \mathrm{~N}-\mathrm{GLY}$ was used at nominal concentration of $100 \mathrm{ng} \mathrm{mL}^{-1}$ in the instrument. The system was extracted with $25 \mathrm{~mL}$ of a $100 \mathrm{mM} \mathrm{K} \mathrm{HPO}_{4}$ buffer at $\mathrm{pH}=9$ by sonication. The extracts were centrifuged and the supernatant derivatized overnight with FMOC-Cl at pH $=9$ (Ronco et al., 2016).
Isotopically labeled atrazine $\left(A T Z-D_{5}\right)$ and glyphosate $\left({ }^{13} \mathrm{C},{ }^{15} \mathrm{~N}-\mathrm{GLY}\right)$, both $1000 \mathrm{ng} \mathrm{mL}^{-1}$, were used to evaluate extract holding time and recovery throughout the pesticide analysis procedure.

\subsubsection{Chromatographic analysis}

Pesticides were identified and quantified by GC-MS-TOF (at 1 uma resolution) through the use of a DANI gas chromatograph model MasterGC coupled to time-of-flight mass spectrometer model MasterTOF-MSPlus (DANI Instruments, Milan, Italy). The system was equipped with a Phenomenex ${ }^{\circledR}$ Zebron ZB-SemiVolatiles (30 $\mathrm{m} \times 0.25 \mathrm{~mm}$ i. d. $\times 0.25 \mu \mathrm{m}$ film thickness) column. The oven ramp was set to an initial temperature of $80^{\circ} \mathrm{C}$ (hold $2 \mathrm{~min}$ ), increased to $280{ }^{\circ} \mathrm{C}$ at $10^{\circ} \mathrm{C} \mathrm{min}^{-1}$ (hold $3 \mathrm{~min}$ ), with a total acquisition program of $25 \mathrm{~min}$. Chromatographic conditions included a flow of helium at 
$0,5 \mathrm{~mL} \mathrm{~min}^{-1}$. The injector was set at $250{ }^{\circ} \mathrm{C}$ and the transfer line at $280^{\circ} \mathrm{C}$. The ionization was carried out by electronic impact in positive mode at $70 \mathrm{eV}$ and mass range between 50 and 600 umas.

For the detection and quantification of GLY + AMPA, an Agilent model 1100 liquid chromatograph was used, with ESI ionization source operating in negative mode, coupled to an Agilent model VL single quadrupole mass spectrometer (Agilent Technologies Inc., Miami, FL, USA). Chromatographic separation was performed in a C18 X-SELECT тм column $(75 \mathrm{~mm} \times 4.6 \mathrm{~mm}$ and $3 \mathrm{~mm}$ pore size, from Waters Corp., Milford, MA, USA) using methanol and nanopure water gradient, with $\mathrm{NH}_{4} \mathrm{Ac}$ as ionization additive, according to the methodology described by Ronco et al. (2016).

\subsubsection{Quality control and quality assurance}

For the validation of the extraction methodology, analyzed pesticides were spiked on the sampled sediments. Recovery, linearity, precision, accuracy, and detection and quantification limits (DL and QL) were evaluated according to the criteria set by SANTE 11945/2015.

Both reagent blanks and duplicates were used as quality controls during sediment analysis, and quantification was carried out by an external calibration curve of pesticide standard solutions in a range of 0 $200 \mathrm{ng} \mathrm{mL}^{-1}$.

The analytical criteria applied for the identification and confirmation of pesticide molecules were the relationship between the chromatographic areas of three characteristic ions (quantification $Q$ and confirmation $\mathrm{q}_{1}$ and $\mathrm{q}_{2}$, and the ratio $\mathrm{Q} / \mathrm{q}_{1}$ and $\mathrm{Q} / \mathrm{q}_{2}$ ) and the retention times, in both the standards and the samples (Cervera et al., 2010).

\subsection{Toxicity bioassays}

Standardized whole-sediment toxicity tests were performed using the amphipod Hyalella curvispina as the test organism, following USEPA (2000) protocol recommendations for Hyalella azteca with modifications. In recent years, this amphipod species has been used as a test organism in ecotoxicological assessments (Peluso et al., 2011, 2013a, 2013b). Test organisms were obtained by sieving cultures maintained in dechlorinated tap water in our laboratory.

Toxicity test procedure was previously described by Peluso et al. (2013b). Briefly, five replicates were used for each sediment sample; $100 \mathrm{~mL}$ of sediment and $175 \mathrm{~mL}$ of overlying water were placed in each replicate (24-hour stabilization period), with ten individuals each. Exposure was conducted for 10 days at $21{ }^{\circ} \mathrm{C}$ on a $16: 8$ light/ dark photoperiod. Eighty percent of the water was replaced every $48 \mathrm{~h}$. To verify good water quality, $\mathrm{pH}$, conductivity, ammonia, hardness, and alkalinity (APHA, 1998, methods 4500, 2340, 2320) were measured at the beginning and end of each test, and temperature and dissolved oxygen were measured daily. Measured endpoints were survival and growth (length expressed as millimeters).

Performance criteria for the control sediment required $80 \%$ survival. Each replicate showing amphipod survival higher than 50\% was set for growth analysis by length (Peluso et al., 2013a, 2013b).

\subsection{Statistical analysis}

The normality and variance homogeneity assumptions for the data were assessed by Shapiro-Wilk and Bartlett's tests, respectively. Amphipod survival and growth (length) were evaluated by one-way ANOVA followed by Dunnett's test a posteriori to determine significant differences with respect to the control. Comparisons between sampling campaigns were made by repeated measures ANOVA. The relationships between variables were assessed through multivariate analysis by principal component analysis (PCA). PCA was based on OM and pesticide chemical contents, and on toxicity test data. Pesticide concentrations below DL were replaced by half the corresponding limit of detection (Delistraty and Yokel, 2007). Significant factors were selected based on the Kaiser principle of accepting Eigenvalues $>1$ (Quinn and
Keough, 2002). In all cases, a significance level of $\alpha=0.05$ was used. Statistical analysis was performed using XL-STAT (Addinsoft 2005, version 7.5.3) and STATISTICA (Stat Soft, Inc. 2001; version 7) software tools.

\section{Results and discussion}

\subsection{Pesticide occurrence and levels}

The list of analyzed compounds comprised 36 pesticides (Table 1): 6 herbicides, 5 pyrethroids, 6 organophosphates, 15 organochlorines (including metabolites), and 4 fungicides. Average recovery $\left(100 \mathrm{ng} \mathrm{mL}^{-1}\right.$ on instrumental injection) for all the analyzed pesticides was $102 \% \pm 8 \%$ $(n=4)$. The recoveries obtained were in the range of $60 \%$ to $140 \%$, deemed acceptable for the analysis of pesticide residues (SANTE 11945/2015). Linearity, precision, accuracy, and detection and quantification limits (DL and QL) for instrumental analysis were acceptable in concordance with Bonansea et al. (2013) and equivalent to those obtained in other studies where QuEChERS methodology was employed (Brondi et al., 2011; Masiá et al., 2015). For glyphosate, these analytical criteria were acceptable and in agreement with the methodological validation reported by Ronco et al. (2016). The sediments contained $30 \%$ to $65 \%$ humidity and $2 \%$ to $9 \%$ organic matter (OM). All samples had fines contents $>90 \%$, which classifies them as clay-loam. Since the pesticide data set obtained from the bottom sediment did not conform to a normal distribution ( $\alpha=0.05)$, nonparametric statistics were used.

Pesticide occurrence was detected at $100 \%$; that is, in all the sampled sites, at least one pesticide was detected. In Argentina, at regional scale, throughout the core area of extensive agricultural production, pesticides residues were quantified in all of the bottom sediments sampled in the lower Paraná-Paraguay basin (Ronco et al., 2016; Etchegoyen et al., 2017). However, no studies were found that describe the entry and environmental fate of pesticides associated with horticulture, a very important activity in the country as well as in the region. In Australia, Thoma and Nicholson (1989) detected pesticides in 100\% of sediment samples from streams draining a horticultural catchment. Thus, pesticide sediment occurrence is a consequence not only of extensive agricultural activity but also of horticulture.

Among the types of pesticides studied, there was a change in the herbicides profile between sampling campaigns (Fig. 2). During CAMP1, the occurrence (\%) of the herbicides atrazine (80\%), glyphosate (60\%) and AMPA (100\%) was detected at concentrations (minimummaximum) of 5.1-32.7, 11.0-98.9, 18.0-54.2 $\mathrm{ng} \mathrm{g}^{-1} \mathrm{dw}$, respectively. Trifluralin (TRF) was only detected in S3, at a concentration six times higher than the maximum for glyphosate, the most used herbicide in the country (Leguizamón, 2013; PwC, 2014). During CAMP2, glyphosate (GLY) and AMPA were found in concentrations (minimum-maximum) of 211.5-404.4 and 86.2-224.9 $\mathrm{ng} \mathrm{g}^{-1} \mathrm{dw}$. When comparing the campaigns site by site (Wilcoxon's test), statistical differences were found $(\mathrm{p}=0.04)$, denoting trends in use (Battaglin et al., 2014). In both sampling campaigns, AMPA was detected in all of the samples. Since AMPA is an environmental metabolite of GLY, it can be inferred that where AMPA is detected, GLY was present at some point in time (Schuette, 1998). Since GLY has a half-life of up to 215 days in sediments (Grunewald et al., 2001), this showed the continuous input/circulation and consequent biotransformation of GLY into AMPA in the study area, as described in other studies (Battaglin et al., 2014). Furthermore, there was an increase in GLY and AMPA concentrations between campaigns. The presence of this pesticide could be due to mobilization from distant extensive agricultural fields surrounding the horticultural ring; or it may be the result of its use in weed control around greenhouses or in chemical fallow outdoors (Neal, 2015). Regardless of its source, GLY is used across all types of agricultural activities, and therefore cannot be considered as a compound to describe waterway pollution due to any particular agricultural activity. 
Table 1

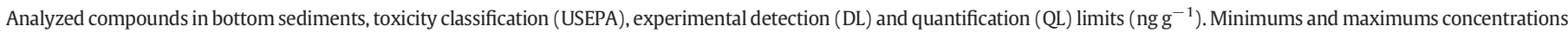
of detected compounds, expressed in $\mathrm{ng} \mathrm{g}^{-1} \mathrm{dw}$.

\begin{tabular}{|c|c|c|c|c|c|c|c|}
\hline Compound & Abbreviation & Tox. & DL & $\mathrm{QL}$ & Detection & Minimum & Maximum \\
\hline Glyphosate & GLY & III & 0.5 & 1.1 & Yes & 11 & 404 \\
\hline Aminomethylphosphonic acid & AMPA & n.i. & 0.6 & 2.6 & Yes & 18 & 225 \\
\hline Acetochlor & ATC & III & 0.5 & 0.9 & No & n.d. & n.d. \\
\hline Atrazine & ATZ & III & 0.2 & 0.6 & Yes & 5.1 & 32.7 \\
\hline Trifluralin & TRF & III, IV & 0.02 & 0.05 & Yes & n.d. & 649.04 \\
\hline Pendimethalin & PEN & III & 0.04 & 0.06 & No & n.d. & n.d. \\
\hline Bifenthrin & $\mathrm{BIF}$ & II & 0.1 & 0.2 & No & n.d. & n.d. \\
\hline Cypermethrin & CYP & II & 0.3 & 0.8 & Yes & 4.2 & 14.8 \\
\hline Deltamethrin & DEL & II & 0.7 & 2 & No & n.d. & n.d. \\
\hline Permethrin & PER & II, III & 0.04 & 0.1 & No & n.d. & n.d. \\
\hline Lambda-cyhalothrin & $\lambda$-CYAL & II & 0.1 & 0.2 & Yes & 1.8 & 649.0 \\
\hline Chlorpyrifos & CLP & II & 0.4 & 1.2 & Yes & 79 & 2258 \\
\hline Diazinon & DZN & II, III & 0.2 & 0.6 & No & n.d. & n.d. \\
\hline Malathion & MAL & III & 0.1 & 0.3 & No & n.d. & n.d. \\
\hline Parathion & PAR & I & 0.2 & 0.5 & No & n.d. & n.d. \\
\hline Methyl parathion & Me-PAR & n.i. & 0.7 & 2.0 & No & n.d. & n.d. \\
\hline Fipronil & FIP & II & 0.1 & 0.2 & No & n.d. & n.d. \\
\hline Endosulfanes & END & I & 0.2 & 0.5 & Yes & 13.9 & 14.8 \\
\hline$\alpha$-Lindane & $\alpha-\mathrm{HCH}$ & II & 0.7 & 2.2 & No & n.d. & n.d. \\
\hline$\beta$-Lindane & $\beta-\mathrm{HCH}$ & II & 1.1 & 3.4 & No & n.d. & n.d. \\
\hline$\gamma$-Lindane & $\gamma-\mathrm{HCH}$ & II & 1.2 & 3.5 & No & n.d. & n.d. \\
\hline Heptachlor & $\mathrm{HCL}$ & II & 1.1 & 3.4 & No & n.d. & n.d. \\
\hline Heptachlor epoxide (isomer A) & $\operatorname{HCE}(\mathrm{A})$ & n.i. & 0.2 & 0.6 & No & n.d. & n.d. \\
\hline Heptachlor epoxide (isomer B) & $\mathrm{HCE}(\mathrm{B})$ & n.i. & 1.1 & 3.3 & No & n.d. & n.d. \\
\hline$o, p^{\prime}-\mathrm{DDE}$ & $0, p^{\prime}-\mathrm{DDE}$ & n.i. & 0.1 & 0.2 & No & n.d. & n.d. \\
\hline$p, p^{\prime}-\mathrm{DDE}$ & $p, p^{\prime}-\mathrm{DDE}$ & n.i. & 0.1 & 0.3 & No & n.d. & n.d. \\
\hline Dieldrin & DLD & II & 0.7 & 2.1 & No & n.d. & n.d. \\
\hline Endrin & EDN & I & 1.4 & 4.4 & No & n.d. & n.d. \\
\hline$p^{\prime} p$-DDD & $p^{\prime} \mathrm{p}-\mathrm{DDD}$ & n.i. & 0.6 & 1.7 & No & n.d. & n.d. \\
\hline$o, p^{\prime}-\mathrm{DDT}$ & $o, p^{\prime}-\mathrm{DDT}$ & n.i. & 0.1 & 0.4 & No & n.d. & n.d. \\
\hline$p, p^{\prime}-\mathrm{DDT}$ & $p^{\prime} p$-DDT & II & 4.3 & 13 & No & n.d. & n.d. \\
\hline Aldrin & ALD & II & 1.4 & 4.3 & No & n.d. & n.d. \\
\hline Pyraclostrobin & PYR & II & 0.3 & 0.8 & No & n.d. & n.d. \\
\hline Azoxystrobin & AZX & III & 0.2 & 0.6 & Yes & 0.8 & 153.0 \\
\hline Epoxiconazole & EPX & III & 0.4 & 0.7 & Yes & n.d. & 214.3 \\
\hline Tebuconazole & TEB & II, III & 0.7 & 2.2 & No & n.d. & n.d. \\
\hline
\end{tabular}

Tox.: US EPA Toxicological Classification; n.i.: not informed; n.d.: not detected.

In regards to insecticides (Table 1 ), chlorpyriphos (CLP) presented different behaviors between campaigns: during the first campaign, it was detected in all monitoring sites at concentrations of 78.2 to
$2258.0 \mathrm{ng} \mathrm{g}^{-1} \mathrm{dw}$. The maximum found corresponds to S3, where $649.0 \mathrm{ng} \mathrm{g}^{-1} \mathrm{dw}$ of the pyrethroid lambda-cyhalothrin $(\lambda-\mathrm{CYAL})$ were also detected. In the second campaign, there were no detections of

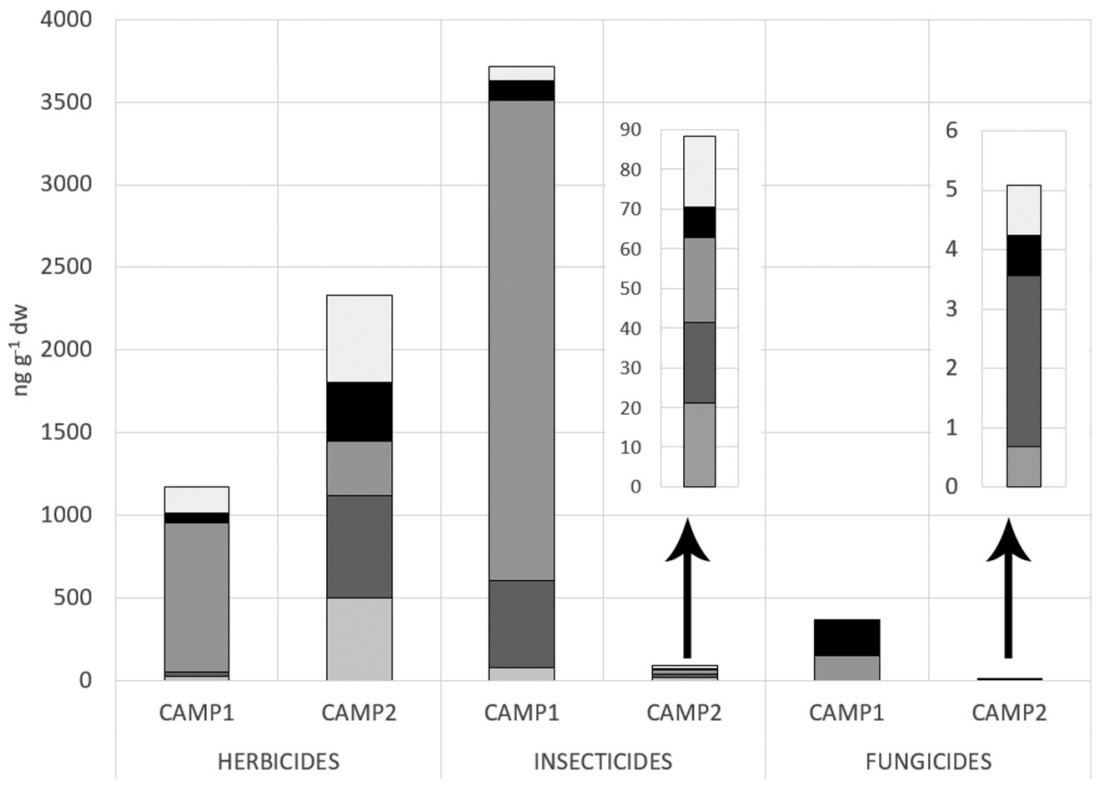

$\square$ SITE $1 \square$ SITE $2 \square$ SITE $3 \quad$ SITE $4 \quad \square$ SITE 5

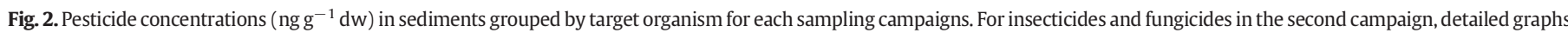
are shown to better depict the concentrations found. 
CLP, but other insecticides, including endosulfan (END) and cypermethrin (CYP), were detected (Fig. 2). The latter, in particular, occurred at detectable levels in all samples. Internationally, the most frequently occurring insecticide in sediments is CLP, with concentrations of $17.4 \mathrm{ng} \mathrm{g}^{-1} \mathrm{dw}$ in streams in California, USA (Phillips et al., 2006), $36.2 \mathrm{ng} \mathrm{g}^{-1} \mathrm{dw}$ in the Ebro River (Spain) (Ccanccapa et al., 2016) and up to $556 \mathrm{ng} \mathrm{g}^{-1} \mathrm{dw}$ in the Túria River (Spain) (Masiá et al., 2015), the latter being still 4 times lower than the highest CLP concentration found in this study. Several studies on rivers in Brazil evaluated insecticides in sediments, finding END as the most frequent (Casara et al., 2012; Miranda et al., 2008). Miranda et al. (2008) also found $\lambda$-CYAL in river sediments from the Pantanal Wetland (Brazil). Additionally, in a study conducted in the state of Mato Grosso (Brazil) during different seasons, Possavatz et al. (2014) reported high concentrations of CLP and $\lambda$-CYAL in dry seasons (July-August) and END in rainy seasons (January-February), consistent with the results for these compounds in our study in the CHP area. In the Chebei stream (China), Li et al. (2013) found a similar pattern in the type of pyrethroids detected, with CYP and $\lambda$-CYAL found at the highest frequencies and concentrations. In US streams, particularly in California, pyrethroids are also found at high frequencies, but the profile differs, with BIF and PER being the most frequently encountered (Weston et al., 2004; Ding et al., 2010). However, pyrethroids are generally found at higher frequencies and concentrations associated with urban water bodies (Ding et al., 2010; Weston and Lydy, 2010). Since these two characteristic compounds were not detected and urbanization at the sampling sites is low, it is fair to assume that horticulture is the main source of pyrethroids in sediments in the Carnaval stream. Statistically, there were significant differences $(p=0.04)$ in insecticides between sampling campaigns, as was observed in the case of GLY + AMPA. This shows that the concentration of pesticides varies based on their application cycles.

During CAMP1, fungicides where detected sparingly and in isolation: azoxystrobin (AZX) was detected in S3 and epoxiconazole (EPX) in S4, in concentrations of approximately $200 \mathrm{ng} \mathrm{g}^{-1} \mathrm{dw}$ and $150 \mathrm{ng} \mathrm{g}^{-1}$ $\mathrm{dw}$, respectively (Fig. 2). No information on EPX concentrations in sediments was found in the literature review. During CAMP2, AZX was the only fungicide detected in all sites but S3, in concentrations ranging from 0.7 to $2.9 \mathrm{ng} \mathrm{g}^{-1} \mathrm{dw}$. These results are consistent with the environmental levels reported in the US (Smalling et al., 2013) and South America (Azevedo et al., 2016), which ranged between $0.5 \mathrm{ng} \mathrm{g}^{-1} \mathrm{dw}$ and $3.8 \mathrm{ng} \mathrm{g}^{-1} \mathrm{dw}$. Given the high variability of fungicide concentrations, the statistical analysis revealed no significant differences between sampling campaigns. However, the distributions of compounds found in each campaign are different, indicating cycles in the use of these pesticides.

Considering there are $>1000$ growers in the CHP, the pesticides levels measured are likely due to the cultivation process itself, the handling of associated machinery, and the conditioning of the produce.

\subsection{Toxicity bioassays}

Overlying water quality characteristics were generally similar among treatments. Measured parameters were in accordance with standardized protocols. Dissolved oxygen in the overlying water was at or above acceptable levels of $2.5 \mathrm{mg} \mathrm{L}^{-1}$ in all treatments throughout the study (USEPA, 2000).

Obtained survival results from the 10-day assays are shown in Fig. 3. In the present work, $\mathrm{S} 1$, the site closest to the headwater, was used as the control. In that site, $90 \%$ and $80 \%$ survival was obtained for CAMP1 and CAMP2, respectively, in compliance with the USEPA (2000) criteria for whole-sediment bioassays.

When analyzing $H$. curvispina survival, the ANOVA showed significant differences $(p<0.05)$ between S3 and the control site in both seasons, with survivals of $0 \%$ for CAMP1 and $50 \%$ for CAMP2. The remaining sites did not show significant differences compared to the control site. The observed toxicity is discussed below in relation to toxic units.

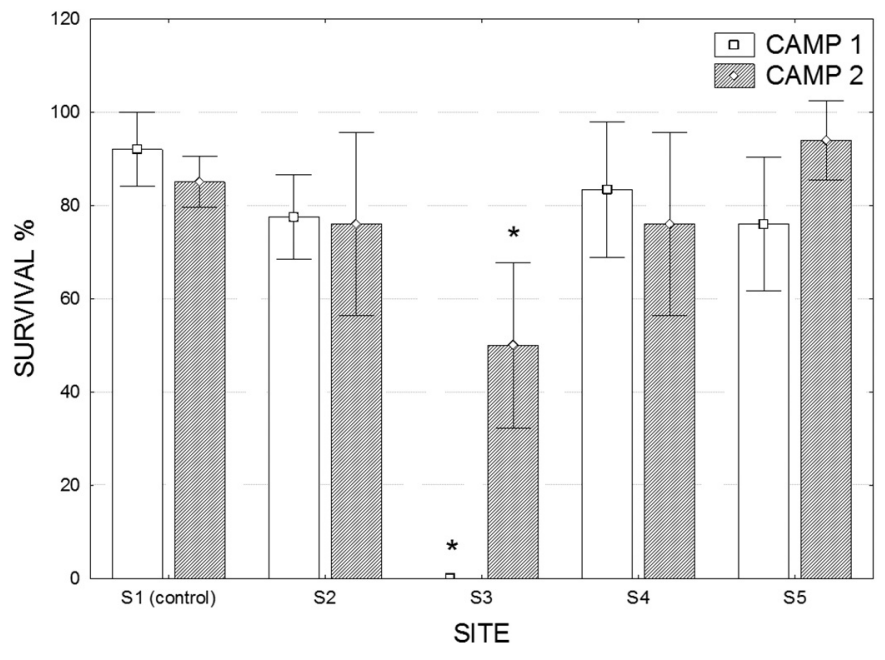

Fig. 3. Average values of the five replicates and standard deviation (mean \pm 0.95 SD) of amphipods $H$. curvispina survival percentage after 10 days of exposure to sediments from the study areas. Asterisks indicate significant difference regarding the control site (S1) $(\mathrm{p}<0.05)$.

In addition, sublethal effects were assessed (Fig. 4) by the length (expressed in $\mathrm{mm}$ ) of the recovered organisms after the assays were finalized. This allows for the detection of sediments showing moderate pollution, even at 10-day exposures (Peluso et al., 2011). Growth was assessed in replicates with survival rates above 50\%. During CAMP1, there were no significant differences between the sampling sites $(\mathrm{p}>0.05)$. However, during CAMP2, there were significant differences between the control and sites 2,3 , and $4(\mathrm{p}=0.04 ; \mathrm{p}=0.007 ; \mathrm{p}=$ 0.03 , respectively), which correspond to the area of highest horticultural production.

Amphipod growth percentage after a 10-days exposure of the control site was $21 \%$ and $30 \%$ for CAMP1 and CAMP2, respectively, when compared to the initial test time. Growth in CAMP1 was below $20 \%$ in all the sites, and as low as 13\% in S2 (S3 could not be evaluated since it generated $100 \%$ mortality), whereas growth in CAMP2 was greater in relation to the initial time for all the sites, S3 being the site that showed the least growth (16\%). The fact that there was no difference among the sampling sites during the first campaign does not mean there were no sublethal effects. The presence of insecticides in the control site could have inhibited growth, so when the statistical test was

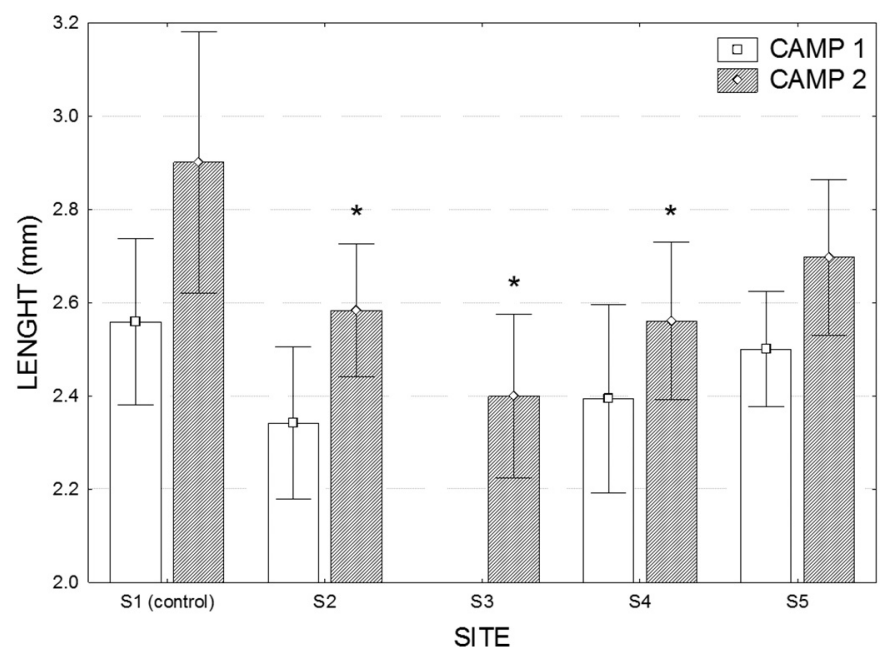

Fig. 4. Average values of the five replicates and standard deviation (mean $\pm 0.95 \mathrm{SD}$ ) of amphipods $H$. curvispina length ( $\mathrm{mm}$ ) after 10 days of exposure to sediments from the study areas. Asterisks indicate significant difference regarding the control site (S1) $(\mathrm{p}<0.05)$. 
run, the differences were not seen. In previous studies using $H$. curvispina as the test organism in moderately contaminated or uncontaminated sediments from rivers and streams in the Pampean region, growth was measured at $25 \%$ and $35 \%$ with respect to the initial group (Peluso et al., 2011, 2013b). In tributaries to the Paraná River, where extensive agriculture is dominant, growth percentages are between $10 \%$ $20 \%$ for $\mathrm{H}$. curvispina with respect to the initial group (Peluso et al., 2013a). These effects could be associated with the presence of insecticides (CYP, CLP, END) detected in the sediments of those water bodies (Etchegoyen et al., 2017), even in lower concentrations than the ones detected in this study.

\subsection{Integrated approach}

\subsubsection{Multivariate approach}

Given the non-normality of the data, in order to explore potential relationships between pesticide measurements and observed effects, the PCA was performed using a Spearman correlation matrix. This procedure was applied to the data sets for each sampling campaign, but only in the first one were there correlations worth noting.

The PCA grouped the 11 variables - two observed toxicity effects, $\mathrm{OM}$ and the concentrations of the eight pesticides detected during CAMP1 - in three main components: F1, F2, and F3, which explain $90.57 \%$ of the total variability. Eigenvalues, variability (\%), and factor loadings for each variable are shown in Table 2. The first component, F1, accounted for $56.0 \%$ of the variance and was positively correlated with \%INHIBITION, TRF, CLP, $\lambda$-CYAL and AZX, and negatively correlated with \%SURVIVAL. This factor indicates that the biological effects on $H$. curvispina may correlate with the presence of insecticides and fungicides. The second component, F2, accounted for $21.6 \%$ of the variances including OM (positively correlated) and the herbicides GLY and ATZ (negatively correlated). Finally, there is nothing worth noting regarding $\mathrm{F} 3$, since EPX is the only variable that contributes to it and was detected only once.

The biplot obtained by the PCA defined by the first two factors is presented in Fig. 5 and shows the distribution of sampling sites and the correlation between pesticide concentrations and effects. Along the F1 axis, which accounts for $>50 \%$ of the total variability, the sampling sites are clearly differentiated, S3 having positive values and the rest showing negatives values. Also worth noting are the positive relationship between \%INHIBITION and CLP, with a 1.000 value in the correlation matrix, and the counterpart negative relationship between \%SURVIVAL and CLP, with a -0.900 value in the correlation matrix. Each of the other three pesticides also found in S3 during CAMP1 - TRF, $\lambda$-CYAL, and AZX - had a positive 1.000 value in the correlation matrix.

\subsubsection{Toxic units}

In addition to the data obtained from the toxicity bioassays, the contribution of each pesticide to the observed toxicity was evaluated by

Table 2

Factor loading and percentage of the total variance explained for 3 factors for the PCA applied to the data set of CAMP1.

\begin{tabular}{llll}
\hline & F1 & F2 & F3 \\
\hline Eigenvalue & 6.163 & 2.377 & 1.423 \\
Variability (\%) & 56.023 & 21.613 & 12.934 \\
\%INHIBITION & 0.854 & 0.222 & 0.278 \\
\%SURVIVAL & -0.909 & -0.225 & 0.161 \\
OM & 0.428 & 0.889 & -0.159 \\
GLY & 0.474 & -0.762 & -0.431 \\
AMPA & 0.608 & -0.281 & -0.663 \\
TRF & 0.929 & -0.037 & 0.168 \\
ATZ & 0.661 & -0.714 & 0.109 \\
CLP & 0.854 & 0.222 & 0.278 \\
$\lambda-C Y A L$ & 0.929 & -0.037 & 0.168 \\
EPX & -0.274 & -0.516 & 0.704 \\
AZX & 0.929 & -0.037 & 0.168
\end{tabular}

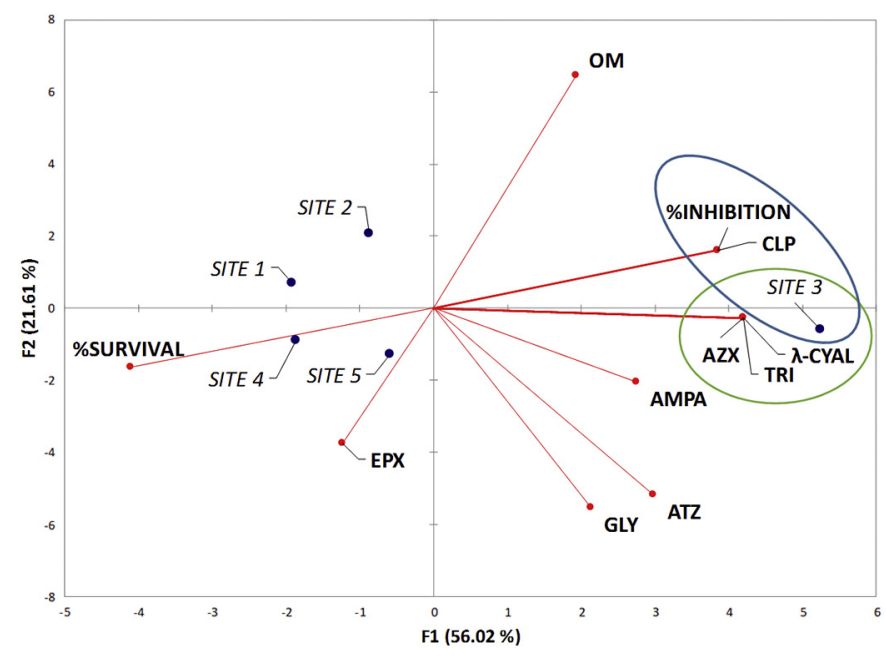

Fig. 5. Principal-components-analysis biplot of variables and the sites sampled for the first two meaningful principal components (accumulated variability 77.64\%). In the figure, the first principal component (F1) is plotted on the ordinate and the second principal component (F2) on the abscissa.

calculating toxic units (TU), estimated from the concentrations found in sediments (Table 3). TUs were calculated by dividing the concentration of each pesticide, normalized to organic carbon in the sediments, by the median lethal concentration (LC50) for each compound. The LC50 values used were obtained from the literature and correspond to the amphipod Hyalella azteca (You et al., 2004; Amweg and Weston, 2007; Ding et al., 2010; Weston et al., 2013), which is known to be very sensitive to pyrethroids (such as CYP and $\lambda$-CYAL) and CLP (Weston and Lydy, 2010). Although $H$. azteca is not a species found in South America, several closely related species ( $H$. curvispina, $H$. pampeana, and $H$. pseudoazteca) are important components of aquatic invertebrate communities in the region. Sediment LC50 values for these native species are not available in the literature. Given that the additive model is the model most commonly used to predict toxicity from pesticide mixtures (Weston et al., 2004), the sum of the TUs was used to assess toxicity.

During CAMP1, the pesticides that contributed to the total toxic units $\left(\mathrm{TU}_{\text {total }}\right)$ were $\lambda$-CYAL and CLP. In $\mathrm{S} 1$, which was chosen as the control site, $<1 \mathrm{TU}_{\text {total }}$ was found $\left(1<\mathrm{TU}_{\text {total }}\right.$, \%SURVIVAL $\left.>80 \%\right)$. In the other sites, $\mathrm{S} 2-\mathrm{S} 5$, calculated $\mathrm{TU}_{\text {total }}$ were greater than one. However, only S3 showed $0 \%$ survival. At that site, the only one where $\lambda$-CYAL was present, $>50 \mathrm{TU}_{\text {total }}$ were found, as a result of high concentrations of $\lambda$-CYAL and CLP. At the other three sites (S2, S4, S5), no significant lethal effects were observed, regardless of the $\mathrm{TU}_{\text {total }}>1$. This might be because CLP, a highly hydrophobic compound, might not have been bioavailable (Widenfalk, 2002). To avoid this error, Li et al. (2017)

Table 3

Toxic units, calculated as the ratio of the carbon-normalized concentration in sediment over the carbon-normalized LC50 (only for the available ones), for the pesticides found in sediments.

\begin{tabular}{|c|c|c|c|c|c|c|c|}
\hline \multirow{4}{*}{$\begin{array}{l}\mathrm{LC}_{50} \text { (ng } \mathrm{g}^{-1} \text { organic } \\
\text { carbon) }\end{array}$} & \multirow{4}{*}{$\begin{array}{l}\text { CYP } \\
380^{\mathrm{a}} \\
\text { CAMP } \\
2\end{array}$} & \multirow{2}{*}{\multicolumn{2}{|c|}{$\frac{\lambda-\mathrm{CYAL}}{450^{\mathrm{a}}}$}} & \multirow{4}{*}{$\begin{array}{l}\text { CLP } \\
1770^{\mathrm{b}} \\
\text { CAMP } \\
1\end{array}$} & \multirow{4}{*}{$\begin{array}{l}\text { END } \\
51700^{c} \\
\text { CAMP } \\
2\end{array}$} & \multirow{2}{*}{\multicolumn{2}{|c|}{$\mathrm{TU}_{\text {total }}$}} \\
\hline & & & & & & & \\
\hline & & CAMP & CAMP & & & CAMP & CAMP \\
\hline & & 1 & 2 & & & 1 & 2 \\
\hline SITE 1 & 0.499 & & & 0.777 & 0.006 & 0.78 & 0.51 \\
\hline SITE 2 & 0.404 & & 0.286 & 3.336 & & 3.34 & 0.69 \\
\hline SITE 3 & 0.288 & 31.201 & 0.090 & 27.597 & 0.006 & 58.80 & 0.38 \\
\hline SITE 4 & 0.215 & & 0.151 & 3.415 & & 3.41 & 0.37 \\
\hline SITE 5 & 0.264 & & 0.132 & 1.235 & & 1.23 & 0.40 \\
\hline
\end{tabular}

a Weston et al. (2013)

b Amweg and Weston (2007).

c You et al. (2004). 
suggests the use of the bioavailable fraction for the calculation of TUs and prediction of toxicity rather than the total extractable concentration. Furthermore, H. azteca mortality increases when TUs for pyrethroids (like $\lambda$-CYAL) reach 0.5 and approaches $100 \%$ when around 10 TU (Weston and Lydy, 2010). Since $\lambda$-CYAL was not found elsewhere, the statistical analysis did not correlate it with the effects observed at the other sites.

For CAMP2, there was 50\% survival in $\mathrm{S} 3$, but with $\mathrm{TU}_{\text {total }}<1$. Generally, if $\mathrm{TU}_{\text {total }}<1$, there is no toxicity (Hintzen et al., 2009). A potential explanation for the observed toxicity is that untested pesticides are contributing to the toxicity evidenced at the site.

\section{Conclusions}

Along the Carnaval creek, the occurrence of pesticides in bottom sediments is continuous and widespread, showing an increase in concentrations as a consequence of the growing horticultural activity downstream in each sampling campaign. The profile of detected compounds changed between sampling campaigns, evidencing the application cycles for the different vegetables being produced.

The herbicide glyphosate was detected in water bodies near vegetable crop areas. Given that this herbicide was also detected at high frequencies and concentrations in previous studies conducted in areas of extensive agriculture-planted with soybeans, maize and wheat-, this compound can be considered ubiquitous and its presence in the environment is independent of the type of agricultural practice.

Since national and international guideline levels for pesticides in sediments are limited and the information for fungicides is non-existent, the application of laboratory bioassays provided a needed tool to evaluate the risk to the benthic fauna. To that end, the use of native species sensitive to pesticide pollution proves relevant for assessing the health status of local communities. There is, however, a need for further studies aimed at generating pesticide acute toxicity data to be used as reference in ecotoxicological research.

Considering the observed toxic effects on the amphipods exposed to sediments, the fact that $H$. curvispina is part of the local fauna associated with bottom sediments, and the reality that pesticides are continually present, it can be concluded that there is risk to the benthic biota and that horticultural practices have negative consequences on nearby watercourses. This is the first study to provide information on the impact of pesticides on aquatic environments near horticultural areas as well as data on the concentration of fungicides in bottom sediments in watercourses in Argentina.

\section{Acknowledgments}

This research was supported by grants from ANPCyT PICT 20123031 and ANPCyT PICT 2014-0919. The authors would like to thank Julieta Pisani McCarthy for her valuable comments and suggestions to improve the quality of the paper. We are deeply grateful to Dr. Alicia "Nina" Ronco, one of the researchers who introduced the study of ecotoxicology in Argentina. She was a teacher, a mentor and a friend. Her loss is mourned by all those lucky to have known her. This paper is a simple and humble tribute to her name.

\section{References}

Amweg, E.L., Weston, D.P., 2007. Whole-sediment toxicity identification evaluation tools for pyrethroid insecticides: II. Esterase addition. Environ. Toxicol. Chem. 26 (11): 2397-2404. http://dx.doi.org/10.1897/07-018R.1.

Anastassiades, M., Lehotay, S.J., 2003. Fast and easy multiresidue method employing acetonitrile extraction/partitioning and "dispersive solid-phase extraction" for the determination of pesticide residues in produce. J. AOCA Int. 86 (2), 412-431.

APHA (American Public Health Association), 1998. In: Clesceri, L.S., Greenberg, A.E., Eaton, A.D. (Eds.), Standard Methods for the Examination of Water and Wastewater, 20th ed. American Public Health Association, Washington, DC.

ASTM (American Society for Testing and Materials), 2002. Standard Guide for Collection, Storage, Characterization, and Manipulation of Sediments for Toxicological Testing (E1391-02)
Azevedo, J.C.R., de Moura, E.R.R., dos Santos, M.M., 2016. Determinação de pesticidas na água e sedimento do rio piquiri. Revista em Agronegócio e Meio Ambiente 9: 651-671. http://repositorio.utfpr.edu.br/jspui/handle/1/841.

Banda Noriega, R.B., Ruiz de Galarreta, A., 2002. Riesgo de contaminación hídrica subterránea por la actividad industrial, cuenca de los arroyos Martin y Carnaval, Buenos Aires. Argentina. Groundwater and Human Development, pp. 153-162.

Battaglin, W.A., Meyer, M.T., Kuivila, K.M., Dietze, J.E., 2014. Glyphosate and its degradation product AMPA occur frequently and widely in U.S. soils, surface water, groundwater, and precipitation. J. Am. Water Resour. Assoc. 50 (2):275-290. http://dx.doi. org/10.1111/jawr.12159.

Bonansea, R.I., Ame, M.V., Wunderlin, D.A., 2013. Determination of priority pesticides in water samples combining SPE and SPME coupled to GC-MS. A case study: Suquía River basin (Argentina). Chemosphere 90:1860-1869. http://dx.doi.org/10.1016/j. chemosphere.2012.10.007.

Brondi, S.H.G., De MacEdo, A.N., Vicente, G.H.L., Nogueira, A.R.A., 2011. Evaluation of the QuEChERS method and gas chromatography-mass spectrometry for the analysis pesticide residues in water and sediment. Bull. Environ. Contam. Toxicol. 86 (1):18-22. http://dx.doi.org/10.1007/s00128-010-0176-9.

Burton, G.A., Landrum, P.F., 2003. Toxicity of sediments. In: Middleton, G.V., Church, M.J., Corigilo, M., Hardie, L.A., Longstaffe, F.J. (Eds.), Encyclopedia of Sediments and Sedimentary Rocks. Kluwer Academic Publishers, pp. 748-751.

Casara, K.P. Vecchiato, A.B. Lourencetti, C. Pinto, A.A. Dores, E.F.G.C. 2012. Environmental dynamics of pesticides in the drainage area of the São Lourenço River headwaters, Mato Grosso State, Brazil. J. Braz. Chem. Soc. 23 (9):1719-1731. http://dx.doi.org/10. 1590/S0103-50532012005000037.

Ccanccapa, A., Masiá, A., Navarro-Ortega, A., Picó, Y., Barceló, D., 2016. Pesticides in the Ebro River basin: occurrence and risk assessment. Environ. Pollut. 211:414-424. http://dx.doi.org/10.1016/j.envpol.2015.12.059.

Cervera, M.I., Medina, C., Portolés, T., Pitarch, E., Beltrán, J., Serrahima, E., ... Hernández, F., 2010. Multi-residue determination of 130 multiclass pesticides in fruits and vegetables by gas chromatography coupled to triple quadrupole tandem mass spectrometry. Anal. Bioanal. Chem. 397 (7):2873-2891. http://dx.doi.org/10.1007/s00216010-3597-8.

CHBA (Censo Hortiflorícola de Buenos Aires), 2006. Ministerio de Asuntos Agrarios y Ministerio de Economía de la Prov (de Buenos Aires).

De Gerónimo, E., Aparicio, V.C., Barbaro, S., Portocarrero, R., Jaime, S., Costa, J.L., 2014. Presence of pesticides in surface water from four sub-basins in Argentina. Chemosphere 107:423-431. http://dx.doi.org/10.1016/j.chemosphere.2014.01.039.

Delistraty, D., Yokel, J., 2007. Chemical and ecotoxicological characterization of Columbia River sediments below the Hanford site (USA). Ecotoxicol. Environ. Saf. 66 (1):16-28. http://dx.doi.org/10.1016/j.ecoenv.2005.10.008.

Ding, Y., Harwood, A.D., Foslund, H.M., Lydy, M.J., 2010. Distribution and toxicity of sediment-associated pesticides in urban and agricultural waterways from Illinois, USA. Environ. Toxicol. Chem. 29 (1):149-157. http://dx.doi.org/10.1002/etc.13.

Donkor, A., Osei-Fosu, P., Nyarko, S., Kingsford-Adaboh, R., Dubey, B., Asante, I., 2015. Validation of QuEChERS method for the determination of 36 pesticide residues in fruits and vegetables from Ghana, using gas chromatography with electron capture and pulsed flame photometric detectors. J. Environ. Sci. Health., Part B 50 (8):560-570. http://dx.doi.org/10.1080/03601234.2015.1028833.

DP (Defensor del Pueblo), 2015. Relevamiento de la Utilización de Agroquímicos en la Provincia de Buenos Aires. Mapa de Situación e Incidencia Sobre la Salud. Defensor del Pueblo, Buenos Aires, Argentina, p. 533.

Etchegoyen, M.A., Ronco, A.E., Almada, P., Abelando, M., Marino, D.J., 2017. Occurrence and fate of pesticides in the Argentine stretch of the Paraguay-Parana basin. Environ. Monit. Assess. 189 (2):63. http://dx.doi.org/10.1007/s10661-017-5773-1.

Friberg, N., Lindstrøm, M., Kronvang, B., Larsen, S.E., 2003. Macroinvertebrate/sediment relationships along a pesticide gradient in Danish streams. Hydrobiologia 494: 103-110. http://dx.doi.org/10.1023/A:1025493627272.

Grunewald, K., Schmidt, W., Unger, C., Hanschmann, G., 2001. Behavior of glyphosate and aminomethylphosphonic acid (AMPA) in soils and water of reservoir Radeburg II catchment (Saxony/Germany). J. Plant Nutr. Soil Sci. 164:65-70. http://dx.doi.org/ 10.1002/1522-2624(200102)164:1<65::AID-JPLN65>3.0.CO;2-G.

Hintzen, E.P., Lydy, M.J., Belden, J.B., 2009. Occurrence and potential toxicity of pyrethroids and other insecticides in bed sediments of urban streams in central Texas. Environ. Pollut. 157 (1):110-116. http://dx.doi.org/10.1016/j.envpol.2008.07. 023.

Hunt, L., Bonetto, C., Resh, V.H., Buss, D.F., Fanelli, S., Marrochi, N., Lydy, M.J., 2016. Insecticide concentrations in stream sediments of soy production regions of South America. Sci. Total Environ. 547:114-124. http://dx.doi.org/10.1016/j.scitotenv.2015.12.140.

Jergentz, S., Mugni, H., Bonetto, C., Schulz, R., 2005. Assessment of insecticide contamination in runoff and stream water of small agricultural streams in the main soybean area of Argentina. Chemosphere 61 (6):817-826. http://dx.doi.org/10.1016/j. chemosphere.2005.04.036.

Kreuger, J., Graaf, S., Patring, J., Adielsson, S., 2010. Pesticides in surface water in areas with open ground and greenhouse horticultural crops in Sweden 2008. Technical Report. Uppsala: (NL, NJ), Dept. of Soil and Environment (S), Dept. of Soil and Environment. Sveriges Lantbruksuniversitet. Ekohydrologi, p. 117.

Kronvang, B., Strøm, H.L., Hoffman, C.C., Laubel, A., Friberg, N., 2004. Subsurface tile drainage loss of modern pesticides: field experiment results. Water Sci. Technol. 49 (3): 139-148. https://doi.org/10.1.1.616.9205

Kvíčalová, M., Doubravová, P., Jobánek, R., Jokešová, M., Očenášková, V., Süssenbeková, H., Svobodová, A., 2012. Application of different extraction methods for the determination of selected pesticide residues in sediments. Bull. Environ. Contam. Toxicol. 89 (1):21-26. http://dx.doi.org/10.1007/s00128-012-0622-y

Leguizamón, A., 2013. Geoforum Modifying Argentina: GM Soy and Socio-environmental Change. :pp. 1-12 http://dx.doi.org/10.1016/j.geoforum.2013.04.001. 
Li, H., Sun, B., Lydy, M.J., You, J., 2013. Sediment-associated pesticides in an urban stream in Guangzhou, China: implication of a shift in pesticide use patterns. Environ. Toxicol Chem. 32 (5):1040-1047. http://dx.doi.org/10.1002/etc.2147.

Li, H., Cheng, F., Wei, Y., Lydy, M.J., You, J., 2017. Global occurrence of pyrethroid insecticides in sediment and the associated toxicological effects on benthic invertebrates: an overview. J. Hazard. Mater. 324 (Part):258-271. http://dx.doi.org/10.1016/j.jhazmat. 2016.10.056.

Marino, D., Ronco, A., 2005. Cypermethrin and chlorpyrifos concentration levels in surface water bodies of the pampa Ondulada, Argentina. Bull. Environ. Contam. Toxicol. 75 (4):820-826. http://dx.doi.org/10.1007/s00128-005-0824-7.

Masiá, A., Vásquez, K., Campo, J., Picó, Y., 2015. Assessment of two extraction methods to determine pesticides in soils, sediments and sludges. Application to the Túria River Basin. J. Chromatogr. A 1378:19-31. http://dx.doi.org/10.1016/j.chroma.2014.11.079.

Miranda, K., Cunha, M.L.F., Dores, E.F.G.C., Calheiros, D.F., 2008. Pesticide residues in river sediments from the Pantanal wetland, Brazil. J. Environ. Sci. Health., Part B 43 (8): 717-722. http://dx.doi.org/10.1080/03601230802388843.

Neal, A., 2015. Greenhouse Weed Control, Horticulture Information Leaflets. NC Cooperative Extension Resources (https://content.ces.ncsu.edu/greenhouse-weed-control Retrieved March 2017).

Paixão, J.F., de Oliveira, O.M.C., Dominguez, J.M.L., dosSantos Almeida, E., Correia Carvalho, C., Magalhães, W.F., 2011. Integrated assessment of mangrove sediments in the Camamu Bay (Bahia,Brazil). Ecotoxicol. Environ. Saf. 74:403-415. http://dx.doi.org/ 10.1016/j.ecoenv.2010.10.038

Peluso, L., Giusto, A., Bulus Rossini, G.D., Ferrari, L., Salibián, A., Ronco, A.E., 2011. Hyalella curvispina (Amphipoda) as a test organism in laboratory toxicity testing of environmental samples. Fresenius Environ. Bull. 20, 372-376.

Peluso, L., Abelando, M., Apartín, C.D., Almada, P., Ronco, A.E., 2013a. Integrated ecotoxicological assessment of bottom sediments from the Paraná basin, Argentina. Ecotoxicol. Environ. Saf. 98:179-186. http://dx.doi.org/10.1016/j.ecoenv.2013.09.001.

Peluso, L., Bulus Rossini, G., Salibián, A., Ronco, A., 2013b. Physicochemical and ecotoxicological based assessment of bottom sediments from the Luján River basin, Buenos Aires, Argentina. Environ. Monit. Assess. 185 (7):5993-6002. http://dx.doi.org/10. 1007/s10661-012-3000-7.

Phillips, B.M., Anderson, B.S., Hunt, J.W., Huntley, S. a, Tjeerdema, R. S., Kapellas, N., Worcester, K., 2006. Solid-phase sediment toxicity identification evaluation in an agricultural stream. Environ. Toxicol. Chem. 25 (6):1671-1676. http://dx.doi.org/10. 1897/05-497r1.1.

Possavatz, J., Zeilhofer, P., Pinto, A., Tives, A., Dores, E., 2014. Pesticide residue in bottom sediment in the Cuiabá River watershed, Mato Grosso, Brazil. Ambiente e Agua 9 (1), 83-96.

PwC Argentina, 2014. Agronegocios en Argentina. Año 2014 (https://www.pwc.com.ar/ es/agribusiness/publicaciones/assets/agribusiness-en-argentina-booklet-2014ultimo.pdf. Retrieved January 2017).

Quinn, G.P., Keough, M.J., 2002. Experimental Design and Data for Biologists. Cambridge University Press (537 pp.).

Ronco, A.E., Carriquiriborde, P., Natale, G.S., Martin, M.L., Mugni, H., Bonetto, C., 2008. Integrated approach for the assessment of biotech soybean pesticides impact on low order stream ecosystems of the pampasic region. In: Chen, J., Guo, C. (Eds.) Ecossytem Ecology Research Trends. Nova Science Publisher, Inc., pp. 209-239.

Ronco, A.E., Marino, D.J.G., Abelando, M., Almada, P., Apartin, C.D., 2016. Water quality of the main tributaries of the Paraná Basin: glyphosate and AMPA in surface water and bottom sediments. Environ. Monit. Assess. 188 (8). http://dx.doi.org/10.1007/ s10661-016-5467-0.

Rosendahl, I., Laabs, V., Atcha-Ahowé, C., James, B., Amelung, W., 2009. Insecticide dissipation from soil and plant surfaces in tropical horticulture of southern Benin. West Africa. J. Environ. Monit. 11 (6):1157-1164. http://dx.doi.org/10.1039/b903470f.

Roseth, R., Haarstad, K., 2010. Pesticide runoff from greenhouse production. Water Sci. Technol. 61 (6):1373-1381. http://dx.doi.org/10.2166/wst.2010.040.

SANTE 11945/2015. Guidance document on analytical quality control and method validation procedures for pesticides residues analysis in food and feed. European Commission Directorate - General for Health and Food Safety.

Schuette, J., 1998. Environmental fate of glyphosate. Environmental Monitoring \& Pest Management. Department of Pesticide Regulation, Sacramento (13 pp.).

Smalling, K.L., Reilly, T.J., Sandstrom, M.W., Kuivila, K.M., 2013. Occurrence and persistence of fungicides in bed sediments and suspended solids from three targeted use areas in the United States. Sci. Total Environ. 447:179-185. http://dx.doi.org/10. 1016/j.scitotenv.2013.01.021.

Solis, M., Mugni, H., Hunt, L., Marrochi, N., Fanelli, S., Bonetto, C., 2016. Land use effect on invertebrate assemblages in Pampasic streams (Buenos Aires, Argentina). Environ. Monit. Assess. 188 (9). http://dx.doi.org/10.1007/s10661-016-5545-3.

Thoma, K., Nicholson, B.C., 1989. Pesticide losses in runoff from a horticultural catchment in South Australia and their relevance to stream and reservoir water quality. Environ. Technol. 10 (1):117-129. http://dx.doi.org/10.1080/09593338909384725.

USEPA (Environmental Protection Agency), 2000. Methods for Measuring the Toxicity and Bioaccumulation of Sediment-associated Contaminants With Freshwater Invertebrates. second ed. Office of Science and Technology Office of Water (Report: EPA 600/R-99/064).

Weston, D.P., Lydy, M.J., 2010. Urban and agricultural sources of pyrethroid insecticides to the Sacramento-San Joaquin Delta of California. Environ. Sci. Technol. 44 (5): 1833-1840. http://dx.doi.org/10.1021/es9035573.

Weston, D.P., You, J., Lydy, M.J., 2004. Distribution and toxicity of sediment-associated pesticides in agriculture-dominated water bodies of California's Central Valley. Environ. Sci. Technol. 38 (10):2752-2759. http://dx.doi.org/10.1021/es0352193.

Weston, D.P., Ding, Y., Zhang, M., Lydy, M.J., 2013. Identifying the cause of sediment toxicity in agricultural sediments: the role of pyrethroids and nine seldom-measured hydrophobic pesticides. Chemosphere 90 (3):958-964. http://dx.doi.org/10.1016/j. chemosphere.2012.06.039

Widenfalk, A., 2002. Pesticide Bioavailability in Aquatic Sediments - A Literature Review. Department of Environmental Assessment, Swedish University of Agricultura Sciences.

You, J., Schuler, L.J., Lydy, M.J., 2004. Acute toxicity of sediment-sorbed endrin, methoxychlor, and endosulfan to Hyalella azteca and Chironomus tentans. Bull. Environ. Contam. Toxicol. 73 (3):457-464. http://dx.doi.org/10.1007/s00128-004-0451-8. 